\title{
In vivo antimalarial activity of stem bark extracts of Plumeria alba against Plasmodium berghei in imprinting control region mice
}

This article was published in the following Dove Press journal:

Reports in Parasitology

18 October 2013

Number of times this article has been viewed

\author{
Johnson Nyarko Boampong' \\ Elvis Ofori Ameyaw' \\ Samuel Kyei \\ Benjamin Aboagye \\ Kwame Asare' \\ Richmond Afoakwah' \\ Alex Boye ${ }^{3}$ \\ Jean Hubert Donfack ${ }^{4}$ \\ 'Department of Biomedical and \\ Forensic Sciences, School of \\ Biological Sciences, ${ }^{2}$ Department \\ of Optometry, School of Physical \\ Sciences, ${ }^{3}$ Department of Laboratory \\ Technology, School of Physical \\ Sciences, University of Cape Coast, \\ Cape Coast, Ghana; ${ }^{4}$ Department \\ of Biomedical Sciences, Faculty of \\ Sciences, University of Dschang, \\ Dschang, Cameroon
}

Correspondence: Johnson Nyarko Boampong

Department of Biomedical and Forensic Sciences, School of Biological Sciences, University of Cape Coast, Cape Coast, Ghana

Tel +23322 64I5 4078

Email jonboamus@yahoo.com
Background: The need for new antimalarial agents with a transcriptional mode of action but fewer side effects compared with artemisinin-based combination therapy for malaria has been the preoccupation of scientists in areas where malaria is a menace. Stem bark extracts of Plumeria alba, used traditionally for the treatment of malaria in Ghana, were investigated to evaluate their prophylactic and curative antimalarial properties.

Methods: The antimalarial properties of $P$. abla were probed using aqueous $(30-300 \mathrm{mg} / \mathrm{kg}$ ) and dichloromethane/methanol $(30-300 \mathrm{mg} / \mathrm{kg}$ ) extracts of the plant in imprinting control region mice infected with Plasmodium berghei. For the curative test, the extracts were administered to the infected mice 4 days post-infection. In the prophylactic test, the animals were pre-treated with the extracts for 3 days before challenging them with $P$. berghei infected erythrocytes.

Results: The aqueous extract exerted significant $(P<0.05-0.001)$ effects on $P$. berghei infection, similar to artemether and lumefantrine curatively and sulfadoxine/pyrimethamine prophylactically. However, the dichloromethane/methanol extract reduced the parasitemia curatively $(P<0.05-0.01)$ but not prophylactically.

Conclusion: This study provides evidence to support the antimalarial properties of stem bark extract of $P$. alba in mice.

Keywords: malaria, parasitemia, artemether, lumefantrine, sulfadoxine/pyrimethamine, Ghana

\section{Introduction}

Malaria is a major global public health problem and is the leading poverty-associated disease, directly undermining the achievements of four millennium development goals: the eradication of extreme poverty, reduction of child mortality rates, improvement of maternal health, and combating of HIV/AIDS and other diseases. ${ }^{1}$ The alarming rate at which malaria parasites develop resistance to most of the available and affordable antimalarial drugs is a major concern that urgently requires the development of newer and more effective alternatives. ${ }^{2}$

In the present study, Plumeria alba, commonly known as "white frangipani," from the family Apocynaceae, was studied for its antimalarial activity. Phytochemically, the leaves of $P$. alba contain terpenoids, flavonoids, alkaloids, glycosides, phytosteroids, tannins, and carbohydrates. ${ }^{3}$ Traditionally, the latex from the leaves is used to manage ulcers and herpes. The seeds possess hemostatic properties and the bark is applied as plaster over hard tumors. In addition, the leaves and bark are employed as diuretic, purgative, cardiotonic, and hypotensive agents. ${ }^{4}$ 
Although P. alba stem bark is commonly used traditionally for the treatment of malaria in Ghana, there is little scientific data to support its use for this purpose. Therefore, the study reported here examined the in vivo curative and prophylactic effects of dichloromethane/methanol and aqueous stem bark extracts of $P$. alba against Plasmodium berghei in imprinting control region (ICR) mice, envisaging that the results could be extrapolated to cover human malaria parasites.

\section{Materials and methods}

\section{Chemicals and test agents}

The methanol and dichloromethane used for the extractions were purchased from Sigma-Aldrich (St Louis, MO, USA), the artemether and lumefantrine (A-L) were obtained from Ajanta Pharma Ltd (Mumbai, India), and the sulfadoxine/ pyrimethamine (SP) was obtained from Maxheal Labs Pvt Ltd (Sachin, India).

\section{Collection and identification of plant material}

Stem bark of $P$. alba was obtained from a local herbalist (Alahji Sadik Abubakr of AA Sadik Herbal Centre, Cape Coast, Ghana). The bark was identified and authenticated by a botanist at the University of Cape Coast Herbarium. A voucher specimen with reference number Bio/BMS/161 was prepared and deposited at the Herbarium for reference.

\section{Preparation of extracts}

The stem bark of $P$. alba was washed thoroughly with tap water and sundried. The dry bark was chopped into pieces and milled into coarse powder with a hammer mill (Schutte Buffalo Hammermill, New York, NY, USA). In preparing the aqueous extract of $P$. alba, $200 \mathrm{~g}$ of the stem bark powder was mixed with $2 \mathrm{~L}$ of distilled water. The mixture was maintained at $80^{\circ} \mathrm{C}$ (in a round-bottomed flask fitted with a reflux condenser) in a thermostatically controlled water bath for 48 hours and then filtered. The filtrate was freeze-dried with a Hull Corp 140 Square Foot Freeze Dryer/ Lyophilizer (model 140FS275C; Warminster, PA, USA) into powder (yield 5.2\%) and stored at a temperature of $4^{\circ} \mathrm{C}$ in a refrigerator. The powder was reconstituted in normal saline to the desired concentration and labeled "aqueous extract of $P$. alba" (referred to hereafter as "aqueous extract") for dosing.

Similarly, $200 \mathrm{~g}$ of the stem bark powder was soaked in $2 \mathrm{~L}$ of solvent (dichloromethane/methanol [1:1]) at room temperature for 48 hours then filtered. The filtrate obtained was freeze-dried into powder (yield 3.4\%). Quantities of this powder were reconstituted in normal saline at the desired concentrations to be used in this study and labeled "dichloromethane/methanol of $P$. alba" (D/M) extract.

\section{Screening for secondary metabolites}

The aqueous and D/M extracts were screened to ascertain the presence of phytochemicals using standard procedures described elsewhere..$^{5-8}$

\section{Animals and husbandry}

Eight-week-old male ICR mice (25-30 g) purchased from the Centre for Scientific Research into Plant Medicine, MampongAkwapim, Ghana, were maintained in the Animal House of the Department of Biomedical and Forensic Sciences, University of Cape Coast, Cape Coast, Ghana. The animals were housed in stainless steel cages $(34 \times 47 \times 18 \mathrm{~cm})$ with soft wood shavings as bedding, under ambient laboratory conditions. They were fed on a normal commercial pellet diet (Agricare Ltd, Kumasi, Ghana) and had free access to water. All procedures and techniques used in these studies were in accordance with the National Institute of Health for the Care and Use of Laboratory Animals. ${ }^{9}$ Protocols for the study were approved by the departmental ethics committee (BMS/13/10).

\section{Source of rodent parasite and inoculation of $P$. berghei NK65}

The rodent parasite was sourced from Noguchi Memorial Institute for Medical Research, University of Ghana, Legon, Ghana and maintained alive in mice by continuous intraperitoneal passage every 5 days.

On the day of the experiment, a total inoculum concentration of $9.6 \times 10^{7}$ of $P$. berghei parasitized erythrocytes per $\mathrm{mL}$ was prepared. This was carried out by determining parasite density of the $P$. berghei in the blood of infected mice. The infected blood was first washed with ethylenediaminetetraacetic acid (EDTA)-phosphate-buffered saline (PBS) and then washed twice with only PBS. It was then diluted appropriately (by a factor of 96) with PBS. Following this, each mouse was inoculated on the first day, Day 0 , with $0.2 \mathrm{~mL}$ of infected blood containing $1 \times 10^{6} \mathrm{P}$. berghei parasitized red blood cells.

\section{Effect of aqueous and D/M extracts of $P$. alba on established P. berghei infection}

To assess the curative potential of the aqueous and D/M extracts on established $P$. berghei infection, 48 male mice were each inoculated with $1 \times 10^{6} \mathrm{P}$. berghei on Day 0 . They were then randomly assigned to eight groups $(n=6){ }^{10}$ 
The mice were monitored to ensure establishment of the infection. After 72 hours, each group was treated orally with 30,100 , or $300 \mathrm{mg} / \mathrm{kg} /$ day of aqueous extract (Groups 1-3); 30, 100, or $300 \mathrm{mg} / \mathrm{kg} /$ day of D/M extract (Groups 4-6); 4 mg/kg/day of A-L (standard drug; Group 7); and $10 \mathrm{~mL} / \mathrm{kg} /$ day normal saline daily (control; Group 8) for 5 days. These doses were chosen based on preliminary study in our laboratory. To determine the effectiveness of the extracts, blood was drawn from the tail to determine the parasitemia using the formula: percentage parasitemia $=$ infected red blood cells in 100 fields $\times 100$, divided by total red blood cells $(2,000)$ in the same fields.

A minimum of 100 high-power fields were examined before a thin film was declared negative. Each slide was read independently by two experienced microscopists.

The mean survival time of the mice in each treatment group was determined over a period of 30 days.

\section{Histopathological assessment}

On Day 12, two animals from each group were randomly selected and sacrificed. Their livers were harvested, fixed in 4\% phosphate-buffered paraformaldehyde, and embedded in paraffin. Sections were stained with hematoxylin and eosin, and fixed on glass slides for microscopic examination by an anatomist at the Department of Biomedical and Forensic Sciences, University of Cape Coast.

\section{Prophylactic activity of aqueous and D/M extracts of $P$. alba on $P$. berghei infection}

The method described by Peters ${ }^{11}$ was used to evaluate the prophylactic activity of the extracts. Briefly, 48 male mice were randomly assigned to eight groups $(n=6)$ and each group was pre-treated orally with 30,100 , or $300 \mathrm{mg} / \mathrm{kg} /$ day of the aqueous extract (Groups 1-3); 30, 100, or $300 \mathrm{mg} / \mathrm{kg} /$ day of the D/M extract (Groups 4-6); $1.2 \mathrm{mg} / \mathrm{kg} /$ day SP (the reference drug; Group 7); or $10 \mathrm{mg} / \mathrm{kg} /$ day normal saline (Group 8). The treatment was continued for 3 consecutive days. On the fourth day, all mice were infected with $1 \times 10^{6} \mathrm{P}$. berghei and, 72 hours later, blood drawn from the tail of the mice was used to prepare thick films. The parasite density and percentage chemosuppression for all the treatment groups were determined.

\section{Statistical analysis}

GraphPad Prism for Windows (v 4.03; GraphPad Software, San Diego, CA, USA) was used for all statistical analyses and $P$ values $<0.05$ were considered statistically significant. All data were expressed as mean \pm standard error of the mean (duplicate measurement). The time-course curves were subjected to two-way (treatment $\times$ time) repeated-measures analysis of variance (ANOVA) with Bonferroni's post hoc test. The column graphs were subjected to one-way ANOVA with Tukey's post hoc test.

\section{Results}

Phytochemical screening of the extracts revealed the presence of glycosides and terpenoids for both extracts. Additionally, the $\mathrm{D} / \mathrm{M}$ extract contained coumarins while the aqueous extract contained anthracenes (Table 1).

The aqueous and D/M extracts, as well as the standard antimalarial drug A-L, reduced the parasitemia significantly from the first day of treatment to the final day. All the treatments provided relatively increased the survival time of the mice compared with the control (Table 2). The aqueous extract significantly $(P<0.0001)$ reduced the level of parasitemia from Day 4 post-infection and achieved the highest effect on Day 8 (Figure 1A). The percentage change $(\% \Delta)$ of parasitemia reduction caused by the $30 \mathrm{mg} / \mathrm{kg}$ aqueous extract was $16.25 \%, 22.2 \%, 22.5 \%$, and $8.4 \%$ on Days $5,6,7$, and 8 post-infection, respectively. The $100 \mathrm{mg} / \mathrm{kg}$ aqueous extract treatment also produced a $\% \Delta$ of parasitemia reduction of $18.9 \%, 27.3 \%, 6.2 \%$, and $23.4 \%$ on Days $5,6,7$, and 8 postinfection. Similarly, the $\% \Delta$ of parasitemia reduction by the $300 \mathrm{mg} / \mathrm{kg}$ aqueous extract was $32.2 \%, 33.3 \%, 16.4 \%$, and $16.4 \%$ on Days $5,6,7$, and 8 post-inoculums, respectively (Figure 1A).

The D/M extract significantly $(P<0.0001)$ reduced the level of parasitemia from Day 4 post-infection and achieved the highest effect on Day 8 . The $\% \Delta$ of parasitemia reduction by the $30 \mathrm{mg} / \mathrm{kg} \mathrm{D} / \mathrm{M}$ extract was $23.2 \%, 4.7 \%, 23.4 \%$, and $20 \%$ on Day $5,6,7$, and 8 post-inoculums, respectively (Figure 1B). The $\% \Delta$ of parasitemia reduction by the $100 \mathrm{mg} / \mathrm{kg} \mathrm{D} / \mathrm{M}$ extract was $38.1 \%, 12.4 \%, 24.3 \%$, and $29.1 \%$ on Days 5, 6, 7, and 8 post-inoculums, respectively. The $300 \mathrm{mg} / \mathrm{kg} \mathrm{D} / \mathrm{M}$ extract produced a $\% \Delta$ of parasitemia reduction of $34.3 \%, 30.5 \%, 31.4 \%$, and $24.4 \%$ respectively

Table I Phytochemical screening of Plumeria alba stem bark

\begin{tabular}{lll}
\hline Secondary metabolite tested & Aqueous extract & D/M extract \\
\hline Alkaloids & - & - \\
Glycosides & + & + \\
Anthracenes & + & - \\
Terpenoids & + & + \\
Flavonoids & - & - \\
Coumarins & - & + \\
\hline
\end{tabular}

Notes: $+=$ present; $-=$ absent. 
Table 2 Summary of the effects of aqueous extract of Plumeria alba (aqueous), dichloromethane/methanol extract of $P$. alba $(D / M)$, and artemether and lumefantrine $(A-L)$ on established Plasmodium berghei infection in mice

\begin{tabular}{llll}
\hline Drug & $\begin{array}{l}\% \\
\text { parasitemia }\end{array}$ & $\begin{array}{l}\% \\
\text { chemosuppression }\end{array}$ & $\begin{array}{l}\text { Survival } \\
\text { days }\end{array}$ \\
\hline Control & $35.5 \pm 3.1$ & - & $12 \pm 0.1$ \\
Aqueous $30 \mathrm{mg} / \mathrm{kg}$ & $14.6 \pm 1.8^{* * *}$ & 58.9 & $12 \pm 0.4$ \\
Aqueous $100 \mathrm{mg} / \mathrm{kg}$ & $12.2 \pm 1.6 * * *$ & 65.6 & $13 \pm 0.4$ \\
Aqueous $300 \mathrm{mg} / \mathrm{kg}$ & $11.2 \pm 1 . I^{* * *}$ & 68.5 & $19 \pm 0.3$ \\
D/M $30 \mathrm{mg} / \mathrm{kg}$ & $8.7 \pm 1.7^{* * *}$ & 75.6 & $16 \pm 0.3$ \\
D/M 100 mg/kg & $7.8 \pm 2.5^{* * *}$ & 78.7 & $18 \pm 0.5$ \\
D/M $300 \mathrm{mg} / \mathrm{kg}$ & $7.1 \pm 1.8^{* * *}$ & 80.1 & $25 \pm 0.6$ \\
A-L $4 \mathrm{mg} / \mathrm{kg}$ & $0.14 \pm 0.1 * * *$ & 96.2 & $28 \pm 0.2$ \\
\hline Notes: Values are expressed as mean \pm standard error of the mean. ***P $\leq 0.001$
\end{tabular}

on Days $5,6,7$, and 8 post-inoculums, respectively. The standard antimalarial drug A-L (4 $\mathrm{mg} / \mathrm{kg})$ produced a $\% \Delta$ of parasitemia reduction of $40.4 \%, 42.9 \%, 76.9 \%$, and $94 \%$ on Days $5,6,7$, and 8 post-inoculums, respectively (Figure 1B).

A-L produced the highest $\%$ chemosuppression of $99.6 \%$ on Day 8, which was 1.5 times the highest \% chemosuppression produced by the aqueous extract $(300 \mathrm{mg} / \mathrm{kg})$ and 1.2 times the highest $\%$ chemosuppression produced by the $\mathrm{D} / \mathrm{M}$ extract (Table 2).

Figure $2 \mathrm{~A}-\mathrm{H}$ represent the histopathological assessment of liver in the treated groups of animals. Numerous Kupffer cells were observed in all tissue sections, except

A

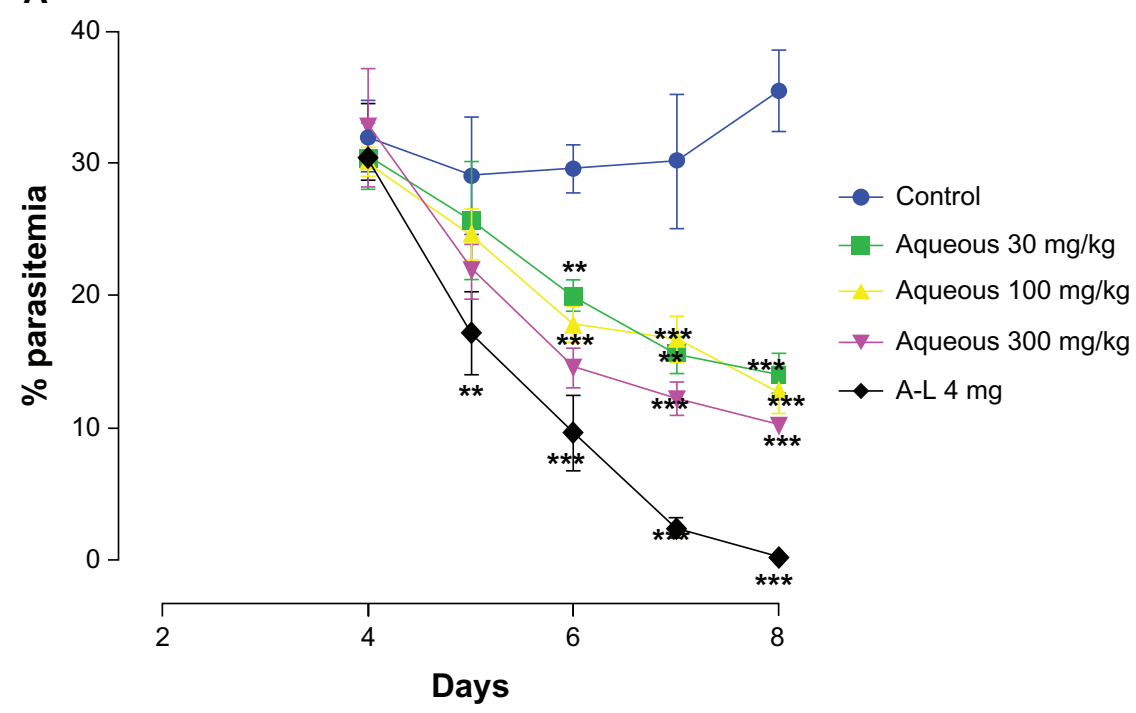

B

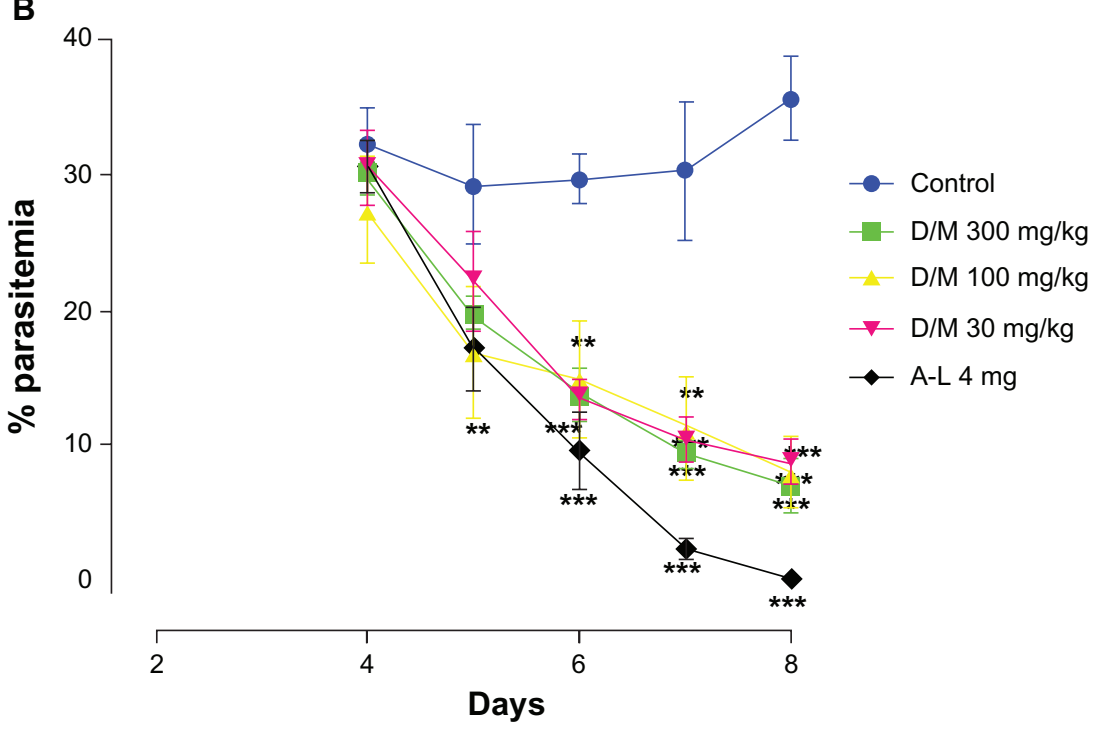

Figure I Effect of (A) aqueous extract of Plumeria alba (aqueous) and artemether and lumefantrine (A-L) and (B) dichloromethane/methanol extract of $P$. alba (D/M) and A-L on the time-course curve of Plasmodium berghei infection in mice.

Notes: Data are presented as mean \pm standard error of the mean. ${ }^{* * P}<0.01$ and $* * * P<0.00$ I compared with the vehicle-treated group (two-way analysis of variance followed by Bonferroni's post hoc test). 
A

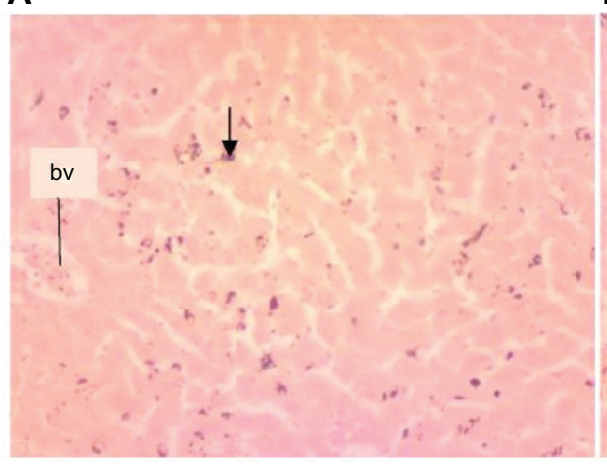

B

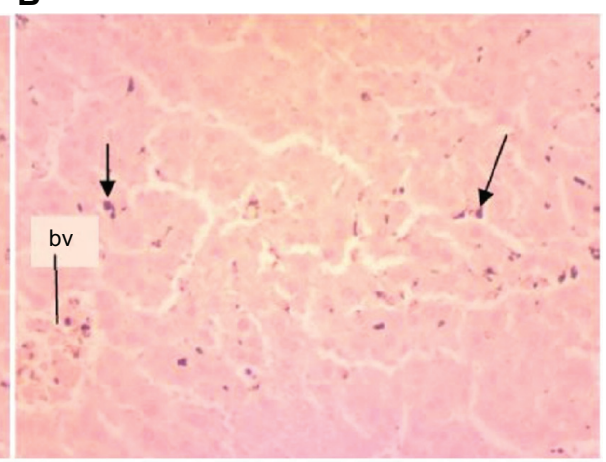

C

D

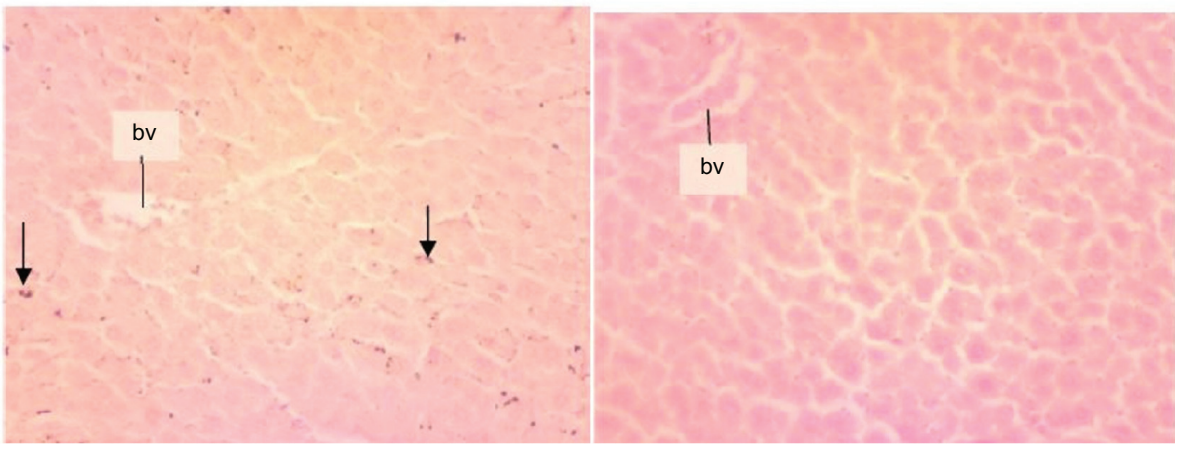

$E$

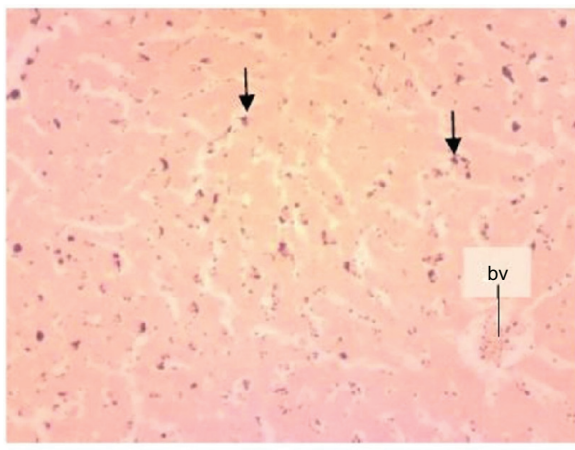

$\mathbf{F}$

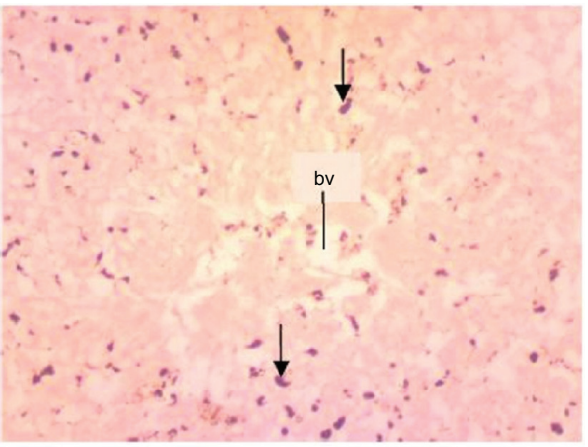

G

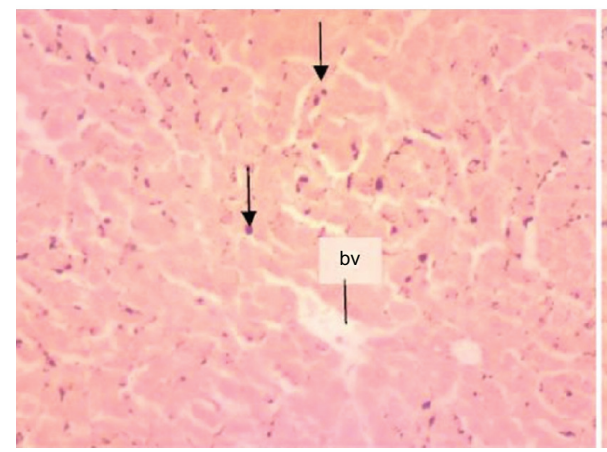

H

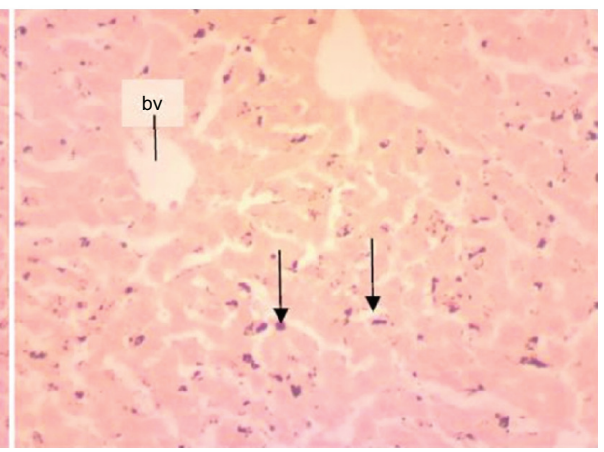

Figure $\mathbf{2}$ Histopathological assessment of liver cells of mice infected with Plasmodium berghei.

Notes: (A) Control (normal saline); (B) dichloromethane/methanol extract of Plumeria alba (D/M) $30 \mathrm{mg} / \mathrm{kg} ;$ (C) D/M I00 mg/kg; (D) D/M $300 \mathrm{mg} / \mathrm{kg}$; (E) aqueous extract of $P$. alba (aqueous) $30 \mathrm{mg} / \mathrm{kg}$; (F) aqueous $100 \mathrm{mg} / \mathrm{kg}$; (G) aqueous $300 \mathrm{mg} / \mathrm{kg}$; (H) artemether and lumefantrine $4 \mathrm{mg} / \mathrm{kg}$. Arrows signify Kupffer cells. Abbreviation: bv, lumen of blood vessel. 
animals treated with $300 \mathrm{mg} / \mathrm{kg} \mathrm{D} / \mathrm{M}$ extract (Figure 2D). The numerous Kupffer cells observed could be attributed to inflammatory reactions in the liver as result of parasite protein sequestration.

The aqueous extract exhibited significant $(P<0.05)$ prophylactic activity against $P$. berghei in vivo at all the three doses tested (Figure 3A) seen as reduction in parasite count compared to the vehicle-treated group. The \% chemosuppressive effect seen at the highest dose employed was $49.4 \%$, which was 1.1 times lower than that of the standard drug SP ( $\%$ chemosuppression of $58.2 \%$ ) (Table 3 ). However, the D/M extract did not show significant prophylactic activity against
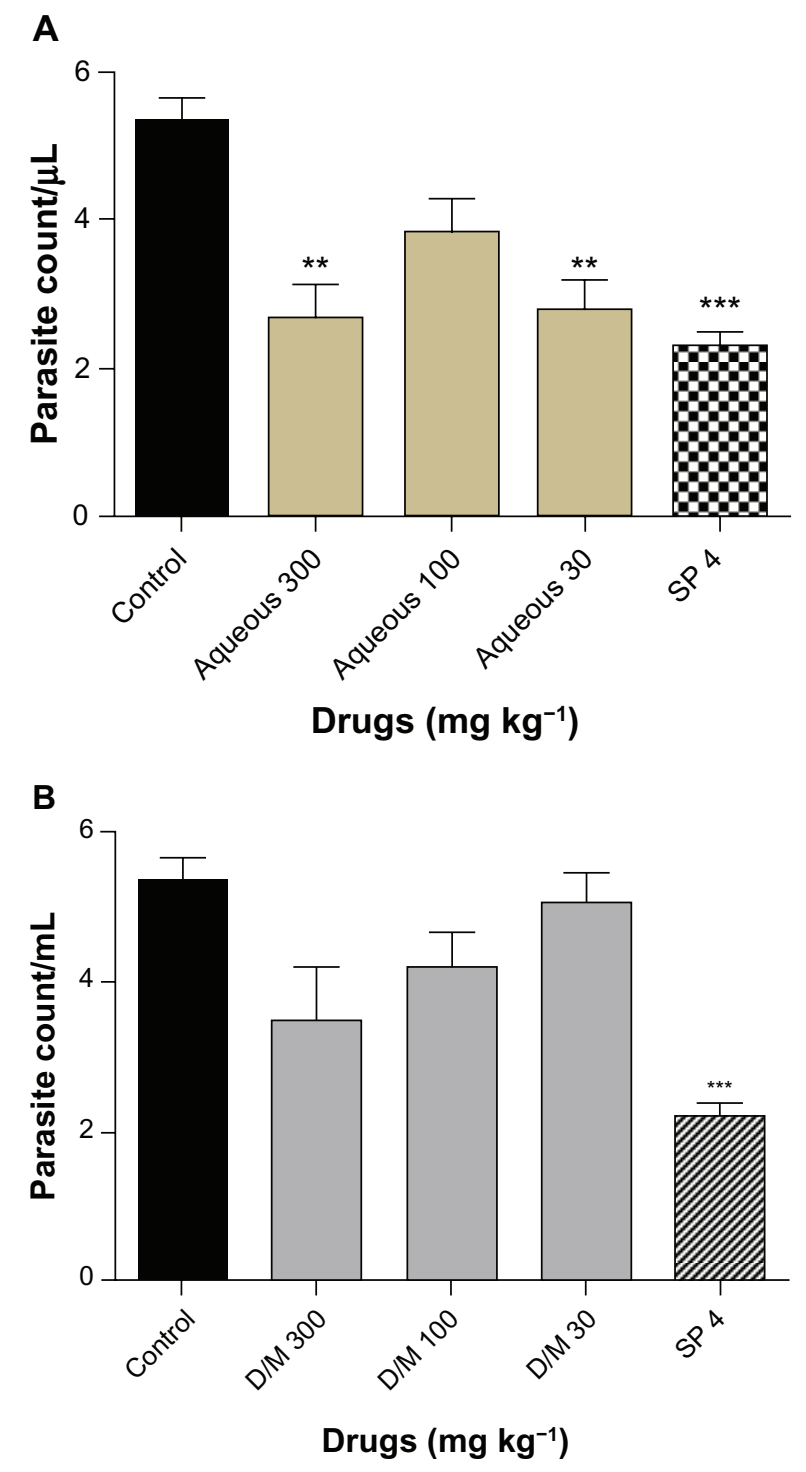

Figure 3 Prophylactic effect of $(\mathbf{A})$ aqueous extract of Plumeria alba and sulfadoxine/ pyrimethamine (SP) and (B) dichloromethane/methanol extract of Plumeria alba (D/M) and SP on residual malaria infection of Plasmodium berghei in mice.

Notes: Data are presented as mean \pm standard error of the mean. $* * * P<0.001$, $* * P<0.01$ compared with vehicle-treated group (one-way analysis of variance followed by Tukey's post hoc test).
P. berghei in vivo (Figure 3B). The maximum \% chemosuppressive effect produced by D/M extract was $36.4 \%, 1.6$ times lower than that of SP (Table 3).

\section{Discussion}

Rodent models of malaria are recommended as a convenient model for preclinical studies of drugs for use in the treatment of human Plasmodial infection. There is ample evidence of the validation of common conventional antimalarial drugs using these models. ${ }^{10}$

The aqueous extract, D/M extract, and A-L exerted curative activities against $P$. berghei infection in the mice, although the D/M extract was not effective prophylactically. The extracts increased the survival time of the mice when compared with survival time in the vehicle-treated groups.

The aqueous and D/M extracts suppressed the growth of $P$. berghei malaria in the curative assay, with highest malaria suppression at $300 \mathrm{mg} / \mathrm{kg}$. The percentage decrease in parasitemia was comparable to $4 \mathrm{mg} / \mathrm{kg}$ A-L, though A-L had the highest chemosuppression. This suggests that $P$. alba stem bark extract can suppress parasite growth if given orally for curative purposes. The oral treatment with $P$. alba on Day 8 revealed that the aqueous and $\mathrm{D} / \mathrm{M}$ extracts had reduced the level of parasitemia to $16.4 \%$ and $20.0 \%$, respectively. Again, the histological assessment of mice hepatocytes revealed relatively low presence of Kupffer cells in tissue treated with $300 \mathrm{mg} / \mathrm{kg} \mathrm{D} / \mathrm{M}$ extract as compared with that treated with $4 \mathrm{mg} / \mathrm{kg}$ A-L.

The presence of phytochemicals such as terpenoids, coumarins, glucosides, and anthracenes observed during qualitative screening for plant secondary metabolites suggests that the extracts may exert some mechanisms that counter the pathological processes of $P$. berghei infection. These metabolites, with profound antioxidant properties, among other mechanisms, ${ }^{12,13}$ may exert their antimalarial effect by decreasing nitric oxide production in Kupffer cells, resulting in killing the parasites. ${ }^{14}$ In addition, secondary metabolites such as anthracenes and glycosides have been shown to possess direct anti-plasmodial effects. It is likely that the aqueous and $\mathrm{D} / \mathrm{M}$ extracts could contain such anthracenes and glycosides, accounting for their anti-plasmodial effect. ${ }^{13,15}$ The relative increase in mean survival time of the extract and A-L treatment groups was due to the clearance of the parasites from the blood of these animals.

For the prophylactic treatment, the D/M extract was not effective, as shown by lower percentages of chemosuppression compared with those of aqueous extract and SP. 
Table 3 Summary of the effects of aqueous extract of Plumeria alba (aqueous), dichloromethane/methanol extract of $P$. alba (D/M), and sulfadoxine/pyrimethamine (SP) on residual $P$. berghei infection in mice

\begin{tabular}{|c|c|c|c|c|c|c|c|c|}
\hline \multirow[t]{2}{*}{ Parameter } & \multirow{2}{*}{$\begin{array}{l}\text { Control } \\
\text { (vehicle) }\end{array}$} & \multicolumn{3}{|c|}{ D/M (mg/kg) } & \multicolumn{3}{|c|}{ Aqueous (mg/kg) } & \multirow{2}{*}{$\frac{\mathrm{SP}(\mathrm{mg} / \mathrm{kg})}{4}$} \\
\hline & & 30 & 100 & 300 & 30 & 100 & 300 & \\
\hline$\%$ chemosuppression & - & 7.2 & 23.6 & 36.4 & 50.9 & 28.3 & 47.2 & 58.2 \\
\hline
\end{tabular}

The aqueous extract and SP had similar percentage chemosuppression against $P$. berghei-infected mice as curative agents. The ineffectiveness of $\mathrm{D} / \mathrm{M}$ extract against $P$. berghei prophylactically may be due to the rapid clearance of the extract or the absence of anthracenes that were present in the aqueous extract.

\section{Conclusion}

As far as the authors are aware, the study reported here is the first to have demonstrated that both $\mathrm{D} / \mathrm{M}$ and aqueous extracts of $P$. alba possess curative antimalarial activities. However, only the aqueous extract possesses prophylactic activity. The efficacy of $P$. alba stem extract can be attributed to the presence of active secondary plant metabolites (coumarins, anthracenes, terpenoids, and glycosides) acting either independently or in concert.

\section{Acknowledgment}

We express our gratitude to Alhaji Sadik Abubakr of AA Sadik Herbal Centre, Nancy Darkoa Darko, Phyllis Tachie, and the workers of the Animal House of the Department of Biomedical and Forensic Sciences, University of Cape Coast.

\section{Disclosure}

All authors contributed equally to this work and declare no conflicts of interest in relation to it.

\section{References}

1. Mishra K, Dash AP, Swain BK, Dey N. Anti-malarial activities of Andrographis paniculata and Hedyotis corymbosa extracts and their combination with curcumin. Malar J. 2009;8:26.
2. Veiga MI, Ferreira PE, Jörnhagen L, et al. Novel polymorphisms in Plasmodium falciparum $\mathrm{ABC}$ transporter genes are associated with major ACT antimalarial drug resistance. PLoS One. 2011;6(5):e20212.

3. Radha R, Shivakumar T, Arokiyaraj S. Pharmacognostical evaluation of Plumeria alba Linn. Res J Pharm Technol. 2008;1(4): 496-501.

4. Prajapati ND, Purohit SS, Sharma AK, Kumar T. Handbook of Medicinal Plants. 2nd ed. Jodphur, India: Agrobios; 2004.

5. Wagner H, Bladt S. Plant Drug Analysis: A Thin Layer Chromatography. 2nd ed. Berlin, Heidelberg, New York, NY: Springer Verlag; 1996.

6. Glasl H. Zur Photometrie in der Drogenstandiserung. [Photometry in drug standardization] Deutsche Apotheker Zeitung. 1983;123(42): 1979-1987.

7. Harborne JB. Phytochemical Methods: A Guide to Modern Techniques of Plant Analysis. 3rd ed. London: Chapman and Hall; 1998.

8. Kujur RS, Singh V, Ram M, et al. Antidiabetic activity and phytochemical screening of crude extract of Stevia rebaudiana in alloxan-induced diabetic rats. Pharmacognosy Res. 2010;2(4):258-263.

9. National Institutes of Health, Office of Science and Health Reports. 1996. Guide for Care and Use of Laboratory Animals. Publication no 83-23. Bethesda, MD: Office of Science and Health Reports, Department of Health and Human Services.

10. Ryley JF, Peters W. The antimalarial activity of some quinolone esters. Am J Trop Med Parasitol. 1970;64(2):209-222.

11. Peters W. Drug resistance in Plasmodium berghei Vincke and Lips, 1948. I. Chloroquine resistance. Exp Parasitol. 1965;17(1):80-89.

12. Patel RM, Patel NJ. In vitro antioxidant activity of coumarin compounds by DPPH, Super oxide and nitric oxide free radical scavenging methods. Journal of Advanced Pharmacy Education and Research. 2011;1: $52-68$.

13. Batista R, Silva AJ Jr, de Oliveira AB. Plant-derived antimalarial agents: new leads and efficient phytomedicines. Part II. Non-alkaloidal natural products. Molecules. 2009;14(8):3037-3072.

14. Dondorp AM, Fanello CI, Hendriksen IC, et al; AQUAMAT group. Artesunate versus quinine in the treatment of severe falciparum malaria in African children (AQUAMAT): an open-label, randomised trial. Lancet. 2010;376 (9753):1647-1657.

15. Murakami N, Mostaqul HM, Tamura S, Itagaki S, Horii T, Kobayashi M New anti-malarial flavonol glycoside from Hydrangeae Dulcis Folium. Bioorg Med Chem Lett. 2001;11(18):2445-2447.

\section{Dovepress}

\section{Publish your work in this journal}

Reports in Parasitology is international, peer-reviewed, open access journal publishing original research, reports, reviews and commentaries on all areas of parasitology. The manuscript management system is completely online and includes a very quick and fair peer-review

system. Visit http://www.dovepress.com/testimonials.php to read real quotes from published authors. 